Пархоменко-Куцевіл Оксана, д-р наук держ. упр., проф., ORCID iD 0000-0002-0758-346X E-mail: pkoi@ukr.net,

\title{
ПРОБЛЕМА СЕК'ЮРИТИЗАЦЇ̈ ІСЛАМУ У ФОРМУВАННІ НАЦІОНАЛЬНОЇ БЕЗПЕКИ
}

\author{
https://doi.org/10.32689/2618-0065-2020-4(6)-221-231
}

Анотація. Метою статті є проведення аналізу теоретичних напрацювань 3 питання сек'юритизації ісламу та іiі впливу на формування національної безпеки. У статті обгрунтовано, що сучасні вчені вивчають проблеми сек'юритизації ісламу як проблему радикально спрямованих угруповань та протидію таким проявам у суспільстві. На сьогодні виникла проблема правильного розуміння місця і ролі ісламу як на глобальному, так і на національному рівнях, яке неможливо без відмови від отриманих в останні кілька десятиліть негативних його трактувань i оцінок як на Заході, так і в українському суспільстві. Центральне місце серед них займають міркування про те, що насувається глобальна ісламська революція i «ісламська загроза» всьому іншому «цивілізованому світу». Якщо для мусульман толерантність, духовність, моральність, гуманізм ісламу є зрозумілою істиною, що не вимагає доказів, то для супротивників він характеризується такими епітетами, як «обмеженість», «фанатизм», «радикалізм», «екстремізм», «тероризм» та ін. Проблеми формування глобального безпекового середовища, визначення загроз та формування доктрини національної безпеки світу $\epsilon$ вимогою сьогодення та передбачає вивчення проблем загроз національній безпеці з точки зору впливу на неї релігійних об'єднань та угруповань. Обгрунтовано, що розглядати сек'юритизацію ісламу як інноваційний шлях формування національної безпеки, адже при системній державній політиці спрямованій на підтримку релігійних меншин, формування та підтримку їх культури, традицій можна зменшити радикальні прояви та покращити системи безпеки в суспільстві як українському так і світовому. На сьогодні виникла 
реальна потреба у переосмисленні ролі сек'юритизації ісламу у формуванні та забезпеченні національної безпеки.

Ключові слова: національна безпека, формування державної політики у сферчі релігій, се'юритизація ісламу, формування позитивного іміджу держави, підтримка релігійних меншин.

Постановка проблеми. В останні кілька десятиліть у світі спостерігається прискорений процес радикалізації мусульманської релігії і пов'язаних 3 нею політичних інститутів. В цей рух залучені такі арабські країни, як Єгипет, Сирія, Ліван, Ірак, Лівія, Палестина, Ємен, Йорданія, арабські монархії зони Перської затоки i iнші, а також держави Середнього Сходу - Туреччина, Іран і Афганістан. Феномен радикальної ісламізації $є$ одним 3 основних викликів для національної безпеки не тільки України, а всього світу.

На сьогодні спостерігаються процеси глобалізації, які активно впливають на формування національної безпеки нашої країни, однак така безпека неможлива без формування глобальної системи безпеки всього світу.

Проблеми формування глобального безпекового середовища, визначення загроз та формування доктрини національної безпеки $\epsilon$ вимогою сьогодення та передбачає вивчення проблем загроз національній безпеці з точки зору впливу на неї діяльності релігійних об'єднань та угруповань.

Аналіз останніх досліджень і публікацій. Слід зазначити, що проблематика формування релігійних об'єднань як загрози національній безпеці, політичного ісламу в контексті безпеки Близького Сходу, основних проблем формування позитивного спрямування релігійних об'єднань аналізуються багатьма вченими, наразі: A. Knudsen [1], В. Шепард [2], Д. Вандервал [3, с. 33-51] розглядають еволюцію політичного ісламу і відродження ісламу в Леванте. Ідеологія політичного ісламу i діяльність радикальних ісламістів аналізується у роботах А. Малашенко [4, с. 221], I. Добаева [5], Б. Долгова [6] та ін. Однак, на сьогодні відсутні 
системні напрацювання 3 проблеми формування національної безпеки у сфері сек'юритизації Ісламу.

Мета статті полягає у здійсненні системного аналізу сек'юритизації Ісламу та його впливу на формування національної безпеки.

Виклад основного матеріалу. Історичний досвід демонструє, що релігія несе потужний ідейний потенціал, здатний стимулювати соціальні, економічні, політичні, етнонаціональні, соціокультурні та інші суперечності і конфлікти, таким чином впливаючи на стан національної безпеки.

На нашу думку, при певних умовах релігія може досить легко приймати радикальні і екстремістські форми.

Водночас, релігія, також, може слугувати стримуючим фактором негативного впливу на національну безпеку. Це залежить від багатьох факторів, у тому числі державної політики у сфері релігії та підтримки релігійних меншин, врахування зазначеного фактору при формуванні політики національної безпеки.

На думку В. Хажирокова, необхідно чітко розмежовувати помірні форми ісламу як будь-якої традиційної релігії та іiі радикальних проявів. Радикальний іслам не просто виходить за правові рамки законодавства, а протиставляється багатьом цінностям, правопорядку і елементам правової культури. У той час як помірні релігійні погляди ісламу нарівні 3 православними традиціями не вступають в будь-які протиріччя 3 базовими цінностями, проектуються законодавством, відтворюють їх в духовній і культурній традиції національних та релігійних меншин [7].

Крім того, слід визнати, що при всіх тенденціях i декларованих цінностях правового універсалізму існує об'єктивна потреба в регіоналізації правопорядку в етнічно- i релігійно-складних за своєю структурою регіонах.

На практиці це означає, що спроба зламу історично сформованого регіонального правопорядку призводить до 
політичного конфлікту, зростання сепаратизму і екстремізму, що, по суті, не може і не повинно бути ні метою, ні наслідком світової політики в галузі формування національної i глобальної безпеки.

Водночас, виникнення радикальних форм ісламу обумовлено не культурно-духовним конфліктом, а глобальними економічними інтересами. У зв'язку з цим політико-правові засоби, що запобігають виникненню i розвитку войовничого ісламу, повинні бути спрямовані, перш за все, на джерела політичної і релігійної маніпуляції i пропаганди екстремізму i тероризму. Безпекова функція держави в регіональному просторі набуває особливості, яка обумовлена культурно-релігійними цінностями спільноти, що населяє відповідну територію країни. Даний факт ставить певні вимоги до організації та реалізації безпекової функції $з$ урахуванням регіональної специфіки, зміщуючи акценти 3 формально-юридичної моделі права на історичну.

Релігійна поведінка політиків-ісламістів сьогодні є одним 3 джерел насильницької поведінки. Прихильники конструктивізму переконані, що соціальні конфлікти залежать від когнітивних факторів, таких як ідеологія, націоналізм, етнічні питання і релігія. Названі конструкції, зміцнюючи взаєморозуміння серед членів певних груп, викликають почуття відмінності від інших, і це почуття може вплинути на вибір їх стратегій [8, с. 51]. Вони переконані, що цінності i ідентичності тісно пов'язані, і екстремісти, формуючи свою нову ідентичність, вдаються до конструювання своїх цінностей. Такий підхід сприяє зростанню конфліктності в світі. Наприклад, символічні норми (в даному випадку джихад, шахадат, хілафат і ін.) $€$ керівництвом до дії для суспільства i причиною походження війн, так як існує значущий зв'язок між цими нормами і переконаннями людей. Таким чином, релігійні переконання можуть стати джерелом насильства і конфліктів між державами [9, с. 30]. 


\section{Науковий вісник: Державне управління № 4(6)2020}

Сучасні символи радикального політичного ісламу транснаціональні терористичні угруповання (ІГ, «Аль-Каїда», «Боко харам» та ін.) засновують свою ідеологію нема на традиційному ісламі. Вони, впливаючи на міжнародний політичний порядок, пропонують альтернативу політичній системі світу [10]. Логічно, що деструктивна діяльність цих угруповань є загрозою і знаходить відображення в сучасному дослідницькому і політичному дискурсі.

На думку Хасана Дж. Насира, традиційний іслам, який був поширений до XIX в. в ісламських суспільствах, регулював, перш за все, повсякденне життя, а не політичне. Політизації ісламу сприяли різні фактори - як зростаючі доктринальні протиріччя з Заходом і проблеми нерозвиненості суспільства, так і процеси колонізації і формування в ісламських країнах диктаторських режимів [11].

Ідеологи політичного ісламу салафітського-такфірітського напряму допускають застосування насильства проти будького. Втілення релігійних доктрин салафітів на практиці стає джерелом насильницьких конфліктів регіонального i, рідше, міжнародного значення. Цей феномен можна розглядати в рамках конструктивістської теорії, яка пов'язує виникнення соціальних суперечок 3 когнітивними конструкціями (ідеологія, націоналізм, нація і релігія). ці конструкції дозволяють зрозуміти почуття відмінності 3 іншими, призводять до формування дихотомії ми - вони, що в контексті ідеології сучасних радикальних організацій означає перехід до насильства, терористичних дій. Релігійні переконання стають важливим фундаментом i ресурсом деструктивної ідеології, грунтом для схвалення і поширення насильства, транснаціонального тероризму [11].

В. Кашнікова звертає увагу на те, що процес адаптації мусульманської громади в умовах переважання індуїстського більшості відбувається дуже повільно, з великими труднощами для мусульман, а значить, і для суспільства в цілому. Це багато в чому залежить і від громади, оскільки мусульманська еліта, а 
тим більше ортодоксальна, фундаменталістська ії частина, не докладає зусиль до співпраці з представниками інших релігій.

Також, важливу деструктивну роль відіграють шовіністичні лідери індуїстської громади, які наживають політичний капітал на антимусульманських настроях в Індії. Для вирішення цієї проблеми потрібні величезні зусилля 3 боку представників політичної еліти і правлячої партії, а також толерантність, взаємоповага, довіра з боку кожної релігійної громади, щоб зберегти національну єдність Індії [12].

Отже, радикальний іслам як комплексна загроза національній безпеці має два серйозних наслідки: 1) руйнування єдиної системи публічного управління; 2) форми політичного впливу радикального ісламу носять виключно деструктивний характер i за своєю природою спрямовані на руйнування традиційних суспільних відносин, політичних зв'язків, систем публічного управління, заміщення їх власними формами публічної ідеології, регулятивними нормами i методами управління. Звідси ключовим інструментом політичного впливу радикального ісламу $\epsilon$ екстремізм і тероризм як регіонального, так і світового рівнів [7].

Проведений аналіз дає підстави зазначити, що сучасні вчені вивчають проблеми сек'юритизації ісламу як проблему радикально спрямованих угруповань та протидія таким проявам у суспільстві.

На нашу думку, слід розглядати сек'юритизацію ісламу як глобальний чинник при формуванні національної безпеки. Треба враховувати, шо при системній державній політиці спрямованій на підтримку релігійних меншин, формування та підтримку їх культури, традицій можна зменшити радикальні прояви та покращити системи безпеки в суспільстві як українському так і світовому.

Висновки та напрями подальших досліджень. Проведений аналіз дає підстави зазначити, що на сьогодні виникла проблема правильного розуміння місця і ролі ісламу 


\section{Науковий вісник: Державне управління № 4(6)2020}

як на глобальному, так i на національному рівнях, яке неможливо без відмови від отриманих в останні кілька десятиліть негативних його трактувань і оцінок як на Заході, так і в українському суспільстві. Центральне місце серед них займають міркування про те, що насувається глобальна ісламська революція і «ісламська загроза» всього іншого «цивілізованого світу». Якщо для мусульман толерантність, духовність, моральність, гуманізм ісламу $\epsilon$ зрозумілою істиною, що не вимагає доказів, то для супротивників він характеризується такими епітетами, як «обмеженість», «фанатизм», «радикалізм», «екстремізм», «тероризм» та ін. На сьогодні виникла реальна потреба у переосмисленні ролі сек'юритизації ісламу як основи формування та забезпечення національної безпеки.

У перспективі подальших розвідок передбачено проаналізувати системи національної безпеки інших країн та вплив на іï формування діяльності регіональних релігійних організацій, у тому числі ісламістського спрямування.

\section{Список використаних джерел}

1. Knudsen A. Political Islam in the Middle East. Chr. Michelsen Institute. 2003. No. 3. Pp. 1-31.

2. Shepard, W. Islam and ideology: Towards a typology. International Journal of Middle East Studies. 1987. № 19. Pp. 307-335.

3. Vandervalle D. Islam in Algeria: Religion, culture, and opposition in a rentier state. Political Islam: Revolution, Radicalism, or Reform? Ed. by J. L.Esposito. Boulder, Colombia: Lynne Rienner, 1997. 281 p.

4. Малашенко А. В. Исламская альтернатива и исламский проект. Московский Центр Карнеги, 2006. 221 с.

5. Добаев И. П., Гонтаренко Н. Н. Радикализация исламского движения на Ближнем и Среднем Востоке: вызовы, риски и угрозы для национальной безопасности Российской Федерации. Россия и мусульманский мир. 2018. №3 (309). URL: https://cyberleninka.ru/article/n/radikalizatsiya-islamskogodvizheniya-na-blizhnem-i-srednem-vostoke-vyzovy-riski-i-ugrozy- 
dlya-natsionalnoy-bezopasnosti-rossiyskoy-1 (дата звернення 20.10.2020).

6. Долгов Б . Политический ислам в современном мусульманском мире // Портал «Перспективыл», 04.10.2007 / Сетевое издание Центра исследований и аналитики Фонда исторической перспективы

URL:

http://www.perspektivy.info/book/politicheskij_islam v sovremenno m_musulmanskom_mire_2007-10-04.htm (дата звернення 20.10.2020).

7. Хажироков В. А. Радикальный ислам на Северном Кавказе в контексте национальной безопасности. Философия права. 2015. №1 (68). URL: https://cyberleninka.ru/article/n/radikalnyy-islam-nasevernom-kavkaze-v-kontekste-natsionalnoy-bezopasnosti (дата звернення 20.10.2020).

8. Wendt A. Social Theory of International Politics. Cambridge University Press, 1999. 429 p.

9. Hasenclever A., Rittber W. War, Security, and Religion. Does Religion Make a Difference? Religion in International Relations: The Return from Exile / Ed. by P.H. Poulos and F. Pettito. New York: Palgrave Mac Millian. 2003. Pp. 107-145.

10. Lebedeva M.M. The Terrorist threat to the world political system. Connections: The Quarterly Journal. 2006. Vol. 5. Iss. 3. Pp. 115124.

11. Хасан Джаббари Насир Политический ислам, терроризм и безопасность на Ближнем Востоке. Вестник МГИМО. 2017. №5 (56). URL: https://cyberleninka.ru/article/n/politicheskiy-islamterrorizm-i-bezopasnost-na-blizhnem-vostoke (дата звернення 20.10.2020).

12. Кашникова В. И. Роль религиозного фактора в контексте национальной безопасности Индии (на примере взаимоотношения индуистов и мусульман). Вестник РУДН. Серия: Международные отношения. 2014. №3. URL: https://cyberleninka.ru/article/n/rol-religioznogo-faktora-v-kontekstenatsionalnoy-bezopasnosti-indii-na-primere-vzaimootnosheniyainduistov-i-musulman (дата звернення 20.10.2020). 


\section{References}

1. Knudsen, A. (2003). Political Islam in the Middle East. Chr. Michelsen Institute, 3, (1-31) [in English].

2. Shepard, W. (1987). Islam and ideology: Towards a typology. International Journal of Middle East Studies, 19, (307-335) [in English].

3. Vandervalle, D. (1997). Islam in Algeria: Religion, culture, and opposition in a rentier state. Political Islam: Revolution, Radicalism, or Reform? Ed. by J. L.Esposito. Boulder, Colombia: Lynne Rienner, (281) [in English].

4. Malashenko, A. V. (2006). Islamskaja al'ternativa i islamskij proekt [Islamic alternative and Islamic project]. Moskovskij Centr KarnegiCarnegie Moscow Center, (221) [in Russian].

5. Dobaev, I.P. \& Gontarenko, N.N. (2018). Radikalizacija islamskogo dvizhenija na Blizhnem i Srednem Vostoke: vyzovy, riski i ugrozy dlja nacional'noj bezopasnosti Rossijskoj Federacii [Radicalization of the Islamic Movement in the Middle East: Challenges, Risks and Threats to the National Security of the Russian Federation]. Rossija $i$ musul'manskij mir - Russia and the Muslim world, 3 (309). URL : https://cyberleninka.ru/article/n/radikalizatsiya-islamskogodvizheniya-na-blizhnem-i-srednem-vostoke-vyzovy-riski-i-ugrozydlya-natsionalnoy-bezopasnosti-rossiyskoy-1. [in Russian].

6. Dolgov, B (2007). Politicheskij islam v sovremennom musul'manskom mire [Political Islam in the modern Muslim world]. Portal «Perspektivy» - Perspectives portal, October 4. Retrieved from http://www. perspektivy.info/book/politicheskij_islam_v_ sovremennom_musulmanskom_mire_2007-10-04.htm. [in Russian].

7. Hazhirokov, V. A. (2015). Radikal'nyj islam na Severnom Kavkaze v kontekste nacional'noj bezopasnosti [Radical Islam in the North Caucasus in the context of national security]. Filosofija prava Philosophy of law, 1 (68). URL https://cyberleninka.ru/article/n/radikalnyy-islam-na-severnomkavkaze-v-kontekste-natsionalnoy-bezopasnosti. [in Russian].

8. Wendt, A. (1999). Social Theory of International Politics. Cambridge University Press, (429) [in English]. 
9. Hasenclever, A. \& Rittber, W. (2003). War, Security, and Religion. Does Religion Make a Difference? Religion in International Relations: The Return from Exile / Ed. by P.H. Poulos and F. Pettito. New York: Palgrave Mac Millian, (107-145) [in English].

10. Lebedeva, M.M. (2006). The Terrorist threat to the world political system. Connections: The Quarterly Journal, 5, 3, (115-124). [in English].

11. Hasan Dzhabbari Nasir (2017). Politicheskij islam, terrorizm i bezopasnost' na Blizhnem Vostoke [Political Islam, Terrorism and Security in the Middle East]. Vestnik MGIMO - MGIMO newspaper, 56. URL : https://cyberleninka.ru/article/n/politicheskiyislam-terrorizm-i-bezopasnost-na-blizhnem-vostoke. [in Russian].

12. Kashnikova Valerija Igorevna (2014). Rol' religioznogo faktora v kontekste nacional'noj bezopasnosti Indii (na primere vzaimootnoshenija induistov i musul'man) [The role of the religious factor in the context of national security of India (on the example of the relationship between Hindus and Muslims)]. Vestnik RUDN - PFUR newspaper, 3. URL : https://cyberleninka.ru/article/n/rol-religioznogo-faktora-v-kontekstenatsionalnoy-bezopasnosti-indii-na-primere-vzaimootnosheniya-induistov-imusulman. [in Russian]. 


\title{
THE PROBLEM OF ISLAM SECURITIZATION IN THE FORMATION OF NATIONAL SECURITY
}

Parkhomenko-Kutsevil Oksana, Doc. Sc. (Pbl Adm.), Prof., Professor of the Department of Public Administration, Interregional Academy of Personnel Management, 03039, Kyiv, Frometivska Str., 2, tel.: 050-922-15-35, e-mail: pkoi@ukr.net, https://orcid.org/0000-0002-0758-346X

\begin{abstract}
The article analyzes the theoretical developments on the issue of securitization of Islam as a basis for the formation of national security. The analysis gives grounds to note that modern scholars study the problems of securitization of Islam as a problem of radical groups and counteraction to such manifestations in society. There is a problem of correct understanding of the place and role of Islam at both the global and national levels, which is impossible without abandoning the negative interpretations and assessments received in the last few decades both in the West and in Ukrainian society today. Central to this is the view that the global Islamic revolution and the "Islamic threat" of the rest of the "civilized world" are imminent. If for Muslims tolerance, spirituality, morality, humanism of Islam is a clear truth that does not require proof, then for opponents it is characterized by such epithets as "limitation", "bigotry", "radicalism", "extremism", "terrorism", etc. The author substantiates that the problems of forming a global security environment, identifying threats and formation the doctrine of national security of the world is a requirement of today and involves the study of problems of threats to national security in terms of religious associations and groups. The article substantiates that the securitization of Islam should be considered as an innovative way of forming national security, because a systemic state policy aimed at supporting religious minorities, forming and supporting culture and traditions can reduce radical manifestations and improve security systems in both Ukrainian and global society. Today, there is a real need to rethink the role of the securitization of Islam as a basis for forming and ensuring national security.
\end{abstract}

Key words: national security, formation of state policy in the sphere of religions, securitization of Islam, formation of a positive image of the state, support of religious minorities. 